\title{
Primary Diffuse-Type Tenosynovial Giant Cell Tumor of the Spine: A Report of 3 Cases and Systemic Review of the Literature
}

\section{Omurganm Primer Difü Tip Tenosinovyal Dev Hücreli Tümörü: 3 Olgu Bildirimi ve Literatürün Sistematik Gözden Geçirilmesi}

\author{
Kai WANG ${ }^{1 *}$, Bin $\mathrm{ZHU}^{1 *}$, Shaomin YANG ${ }^{2}$, Zhongjun $\mathrm{LIU}^{1}$, Miao YU ${ }^{1}$, Xiaoguang $\mathrm{LIU}^{1}$ \\ ${ }_{1}^{1}$ Peking University Third Hospital, Department of Orthopaedics, Beijing, People's Republic of China \\ ${ }^{2}$ Peking University Health and Science Center, Department of Pathology, Beijing, People's Republic of China
}

"Kai Wang and Bin Zhu contributed equally to this study and shared the first authorship.

Corresponding Author: Liu XIAOGUANG / E-mail: xiaoguangliu1966@163.com

\begin{abstract}
Three patients with spinal primary diffuse-type tenosynovial giant cell tumor (DTGCT) received surgical treatment in our department between 2002 and 2012. All 3 patients were female and aged 23, 33, and 44 years. The mean time from symptom onset to diagnosis was 17 months (range, 5-24 months). One case involved the $C 1$ right lateral mass and $C 2$ vertebral body, the second involved the $C 1-2$ left lateral masses and C2 vertebral body, and the third involved the C5-7 left lateral mass and C6 vertebral body. All patients underwent computed tomographyguided biopsy to confirm the diagnosis of tenosynovial giant cell tumor. Gross total resection was achieved in all patients, including 2 piecemeal resections and 1 en-bloc resection. The mean follow-up time was 6 years (range, 1-11 years), and there was no sign of recurrence in the patients. Seventy cases have been identified so far in the English literature. The male to female ratio is 1:1.38. The mean patient age is $38.5 \pm 17.9$ years. The tumor distribution includes 32 cases in the cervical spine, 14 in the thoracic spine, 22 in the lumbar spine, and 1 in the sacrococcygeal region. The recurrence rate for patients who underwent gross total resection was $7.7 \%$, and tumor progression was observed in $66.7 \%$ of patients who underwent subtotal resection. Above all, DTGCT is a rare primary spinal neoplasm. Preoperative image-guided biopsies play an important role in the diagnosis and treatment strategy. Gross total resection is the best treatment strategy and can reduce the recurrence rate.
\end{abstract}

KEYWORDS: Tenosynovial giant cell tumor, Diffuse type, Spinal neoplasms, PVNS, Systemic review

Öz

Bölümümüzde 2002 ile 2012 arasında spinal primer difüz tip tenosinovyal dev hücreli tümörü (DTGCT) olan üç hastanın cerrahi tedavisi yapıldı. Bu üç hasta 23, 33 ve 44 yaşlarındaydı ve hepsi kadındı. Belirtilerin başlangıcından tanıya kadar ortalama süre 17 aydı (aralık, 5-24 ay). Bir olguda C1 sağ lateral kitle ve C2 vertebral cisim tutulması vardı. İkinci olguda C1-2 sol lateral kitleleri ve C2 vertebra cismi tutulmuştu. Üçüncü olguda C5-7 sol lateral kitleleri ve C6 vertebra cismi tutulmuştu. Tüm hastalarda tenosinov yal dev hücreli tümör tanısını doğrulamak için bilgisayarlı tomografi kılavuzluğunda biyopsi yapıldı. Tüm hastalarda gros total rezeksiyon yapıldı. Hastaların ikisinde parça parça ve 1'inde ise en blok halinde rezeksiyon ile gerçekleştirildi. Ortalama takip süresi 6 yıldı (aralık, 1-11 yıl) ve hastalarda bir nüks bulgusu yoktu. İngilizce literatürde şimdiye kadar 70 olgu tanımlanmıştır. Erkek/kadın oranı 1:1,38'dir. Ortalama hasta yaşı 38,5 $\pm 17,9$ yıldır. Tümör dağılımı servikal omurgada 32 olgu, torasik omurgada 14 olgu, lomber omurgada 22 olgu ve sakrokoksigiyal bölgede 1 olgu şeklindedir. Gros total rezeksiyon yapılan hastalarda nüks oranı \%7,7 bulunmuş ve subtotal rezeksiyon yapılan hastaların \%66,7'sinde tümör ilerlemesi gözlenmiştir. Genel olarak DTGCT nadir bir primer spinal neoplazmdır. Preoperatif tomografi kılavuzluğunda biyopsiler, tanı ve tedavi stratejisinde önemli bir rol oynamaktadır. En iyi tedavi gros total rezeksiyondur.

ANAHTAR SÖZCÜKLER: Tenosinovyal dev hücreli tümör, Difüz tip, Spinal neoplazmlar, PVNS, Sistematik gözden geçirme

\section{INTRODUCTION}

Diffuse-type tenosynovial giant cell tumors (DTGCT) are a type of aggressive benign tumor thought to originate from tendon sheaths, bursae, or diarthrodial joint synovium (5). The etiology of DTGCT remains unknown, and DTGCT was previously named extra-articular PVNS because it shares similar histological characteristics with pigmented villonodular synovitis (PVNS) (39). DTGCT occurs mainly in middle-aged women and usually involves large loadbearing joints such as the knee, ankle, and hip, whereas clinical case reports of DTGCT involving the spine are rare. We retrospectively analyzed a case series of 3 patients diagnosed with spinal DTGCT. The common characteristics, imaging and pathological manifestations, diagnosis and 
treatment strategies, and follow-up data from these cases were retrospectively reviewed. Additionally, case reports in the English literature were systematically reviewed.

\section{CASE REPORTS}

\section{Case 1}

Patient 1 was a 23-year-old woman who experienced neck pain and discomfort over a 2-year period. No limitations in the cervical range of motion (ROM) were noted. The neurological examination was completely normal.

Imaging: The computed tomography (CT) examination revealed a $6 \times 4 \times 6 \mathrm{~cm}$ osteolytic lesion on the $C 1$ right lateral mass and the $\mathrm{C} 2$ vertebral body (Figure 1A). Magnetic resonance imaging (MRI) demonstrated a lobulated mass that originated in the $\mathrm{C} 1$ right lateral mass, with significant paravertebral expansion. Heterogeneous isointensity was identified on the T1-weighted images, and high-signal intensity was identified on the T2-weighted images (Figure 1B).

Treatment: A single-stage combined anterior and posterior piecemeal total resection was performed, and stability reconstruction was achieved via a combination of anterior and posterior internal fixation (nail-plate system and occipitocervical fusion with iliac graft). The intraoperative blood loss was 1500 $\mathrm{mL}$, and the surgery duration was $420 \mathrm{~min}$. After 2.5 years, the posterior internal fixation was removed because of unbearable axial neck pain. The postoperative pathological examination confirmed the diagnosis of DTGCT.

Follow-up examination: The follow-up time was 11 years. The CT images taken at the last follow-up examination showed achievement of solid bone fusion and no sign of recurrence (Figure 1C).

\section{Case 2}

The second patient was a 33-year-old woman who experienced neck pain and right hand numbness over a 2-year period. The neurological examination indicated a medial-side sensory loss in the forearm and ring finger.
Imaging: CT images showed a giant osteolytic and expansive bone-destructive lesion centered in the C6 left lateral mass and lamina; the C5 and C7 lateral masses were also involved, and the cortical bone was eroded (Figure 2A). MRI revealed a lobulated mass, with significant expansion to the spinal canal and paravertebral areas. High-signal intensity was identified on the T1-weighted images, and low-signal intensity with patchy high-signal intensity was identified on the T2weighted images (Figure 2B).

Treatment: A single-stage combined anterior and posterior piecemeal total resection was performed. The C6 vertebral body and lamina and the C5-7 left lateral masses were resected. Stability reconstruction was achieved via a combination of anterior and posterior internal fixation (nail-plate fixation from C3-T2 in the posterior approach and a titanium mesh fusion with iliac bone; Figure $2 \mathrm{C}$ ). The intraoperative blood loss was $800 \mathrm{~mL}$, and the surgery duration was $300 \mathrm{~min}$.

Follow-up: The follow-up time was 6 years. The patient's right hand and forearm numbness significantly improved. The CT images at last follow-up examination showed no sign of recurrence (Figure 2D).

\section{Case 3}

The third patient was a 44-year-old woman who experienced neck pain and discomfort over a 2-year period. Her cervical range of motion (ROM) was significantly limited. The neurological examination was normal.

Imaging: Preoperative CT images showed an osteolytic lesion located at the odontoid, the C2 left vertebral body, and the C1-2 left lateral mass, whereas marginal sclerosis was visible (Figure 3A). MRI revealed a lobulated mass with high-signal intensity on the T1-weighted images and low-signal intensity on the T2-weighted images. Obvious enhancement was observed on the gadolinium diethylenetriamine penta-acetic acid (Gd-DTPA)-enhanced (administered intravenously) T1weighted images (Figure 3B).

Treatment: A single-stage combined anterior and posterior en-bloc resection was performed. The tumor capsule was intact. Stability reconstruction was achieved via a posterior
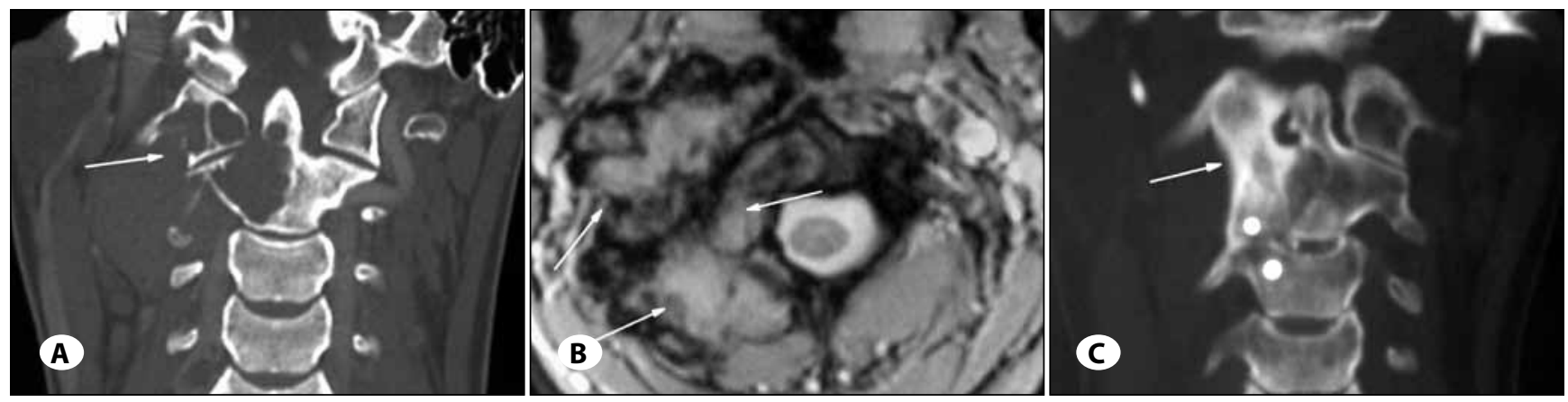

Figure 1: A) Coronal plane computed tomography (CT) image showing an osteolytic lesion of the $\mathrm{C} 1$ right lateral mass and the $\mathrm{C2}$ vertebral body (arrow). B) Lobulated high-signal intensity mass on T2-weighted magnetic resonance imaging (arrow). C) CT image taken 11 years after surgery showed solid bone fusion in the $1-3$ region (arrow). 



Figure 2: A) Computed tomography (CT) images show C6 left accessory-centric osteolytic and expansive bone destruction (arrow). B) Magnetic resonance imaging showed a low-intensity signal with patchy high-density signals on the T2-weighted images; the spinal cord was severely compressed (arrow). C) Postoperative antero-posterior and lateral plain graphs showed the internal fixation positioning. D) CT image taken 6 years after surgery showed no recurrence.
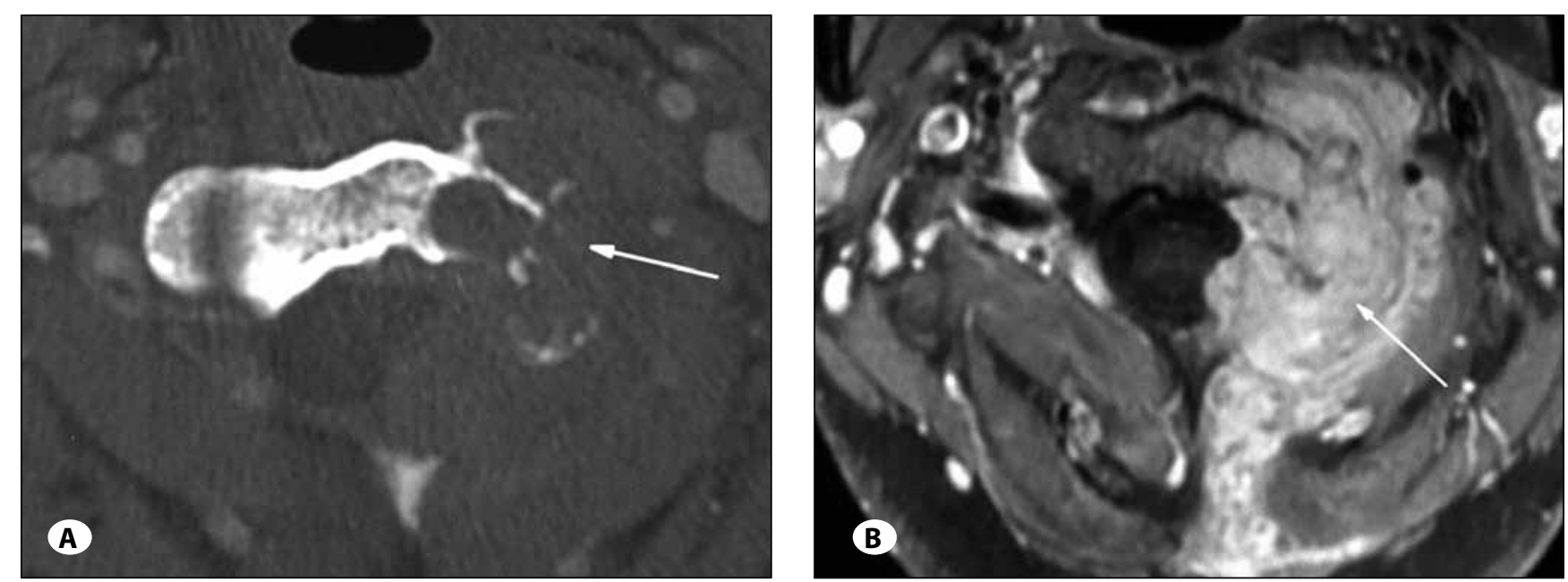

Figure 3: A) Preoperative computed tomography images show bone destruction on the odontoid, the $\mathrm{C} 2$ left vertebral body, and the left accessories of C1-2. B) A lobulated tumor mass with obvious gadolinium (Gd)-DTPA enhancement was observed on T1-weighted magnetic resonances images with intravenous Gd-DTPA administration. 
internal fixation (screw-rod system, occipitocervical fusion with iliac graft). The intraoperative blood loss was $1500 \mathrm{~mL}$, and the surgery duration was 447 min.

Follow-up examination: No recurrence was noted at the 1-year follow-up examination.

\section{Pathological Analysis}

Pathologically, all 3 patients were diagnosed with DTGCT, with the following features that differentiated these tumors from other lesions, especially giant cell tumors of the bone. The tumors were non-circumscribed with infiltrative growth into the surrounding tissues. The clefts appeared as synoviallike and pseudoalveolar spaces, and villous patterns could be detected. Mononuclear histiocyte-like cells with vesicular nuclei were the predominant cell type present. Some of the mononuclear cells contained cytoplasmic hemosiderin. Small numbers of osteoclastic giant cells were irregularly distributed throughout the lesions and were more frequently observed around hemorrhagic foci. Sheets of foam cells and scattered lymphocytes were also detected. No necrosis or other obvious features indicative of malignancy were present in the lesions (Figure $4 A, B)$. The immunohistochemical analysis of the 3 patients is listed in Table I.

\section{Systemic review of case reports in the English literature}

Search strategy: Two reviewers independently searched the Ovid MEDLINE (1950-present), EMBASE (1980-present), and bibliographies for case reports of DTGCT/PVNS involving the spine. The searches were restricted to English language reports.

The following search terms were used: "diffuse-type tenosynovial giant cell tumor," "DTGCT," "pigmented villonodular synovitis,"“PVNS," "giant cell tumor of tendon sheath," "GCTTS," "spinal neoplasms," "spine," and "spine tumor." Any disagreement between the reviewers was resolved by a discussion with the other reviewer. Cases were included if they met the following criteria: a pathological diagnosis of PVNS or DTGCT (giant cell tumor of tendon sheath; GCTTS) and tumors involving the axial skeleton (from atlas to coccyx).

Data extraction: The following information was collected from each case, using a standardized form: author and publication year, tumor location, sex and age, pathological diagnosis, treatment strategy, and follow-up data.

Searching results: After independently reviewing the titles and abstracts identified in the initial search according to the inclusion criteria, 87 cases were included in the full-text screening. Twelve repeatedly reported cases $(13,28), 2$ cases of uncertain PVNS diagnoses (43), and 3 non-English reports $(19,34,37)$ were excluded. A total of 70 cases were included in the meta-analysis (Table II) $(1,3,4,6 \sim 18,20,22,23,25 \sim 29$, 31 33,35,36,38,40 42,44,46 49).

\section{Meta-Analysis}

There were 29 men and 40 women (the gender was unavailable in 1 case) (46), and the male to female ratio was 1:1.38. The
Table I: Immunohistochemical Analysis of the 3 Patients

\begin{tabular}{|l|c|c|c|}
\hline & Patient 1 & Patient 2 & Patient 3 \\
\hline S100 & $(-)$ & $(-)$ & $(+)$ \\
\hline Cytokeratin (mix) & $(-)$ & $(-)$ & $(-)$ \\
\hline CD45 & $(-)$ & $(+)$ & $(+)$ \\
\hline Desmin & $(+)$ & $(+)$ & $(+)$ \\
\hline Vimentin & $(-)$ & $(-)$ & $( \pm)$ \\
\hline
\end{tabular}

mean age of all patients was $38.5 \pm 17.9$ years. The tumor distribution included 32 cases involving the cervical spine, 14 cases involving the thoracic spine, 22 cases involving the lumbar spine, and 1 case involving the sacrococcygeal region; the location of 1 case was unavailable (13).

Regarding the imaging manifestations, 50 patients $(71.4 \%)$ reported that the tumors originated from the facet joint, 46 $(65.7 \%)$ reported spinal canal tumor expansions (epidural or intradural), and $18(25.7 \%)$ reported remarkable paravertebral tumor expansion of the tumor. Regarding the pathological diagnoses, 11 patients were diagnosed with DTGCT/GCTTS, 4 with PVNS/DTGCT, 53 with PVNS, and the other 2 cases with malignant PVNS.

Our systemic review mainly focused on the treatment strategies and prognosis for spinal PVNS/DTGCT. Among the 70 reported cases, imaging data from follow-up examinations performed beyond 1 year were available in 35 cases. Twenty-six patients $(26 / 35,74.3 \%)$ underwent gross total resection (GTR) of the tumors ( 24 underwent GTR, 1 underwent GTR combined with radiation therapy, and 1 underwent GTR combined with chemotherapy and radiation therapy). No tumor recurrence was observed at the last follow-up examination in 24 cases $(24 / 26,92.3 \%)$, and recurrence was observed in 2 cases (cases 16 and $18 ; 2 / 26,7.7 \%)$. Nine patients $(9 / 37,24.3 \%)$ underwent subtotal resection of the tumor, and tumor progression was observed in 6 cases $(6 / 9,66.7 \%$; includes 2 cases of malignant transformation and metastasis).

\section{DISCUSSION}

Tenosynovial giant cell tumors (TGCT) are aggressive soft tissue tumors that belong to a group of lesions that originate from the bursa or the tendon sheath synovium (30). These lesions are classified into 3 types based on their location and encapsulation: nodular tenosynovitis, a localized extraarticular type; PVNS, a diffuse, non-encapsulated intraarticular type; and GCTTS or TGCT, a diffuse, extra-articular growth type. These various tumor types share similar histological findings. TGCT can further be classified as focaltype (FTGCT) or diffuse-type (DTGCT). FTGCT primarily occurs in the fingers and displays clear boundaries, whereas DTGCT occurs in large load-bearing joints such as the knee, hip, ankle, shoulder and elbow and lacks clear boundaries or displays capsular invasion (45); however, DTGCT, PVNS, and GCTTS were intermixed in the literature. 


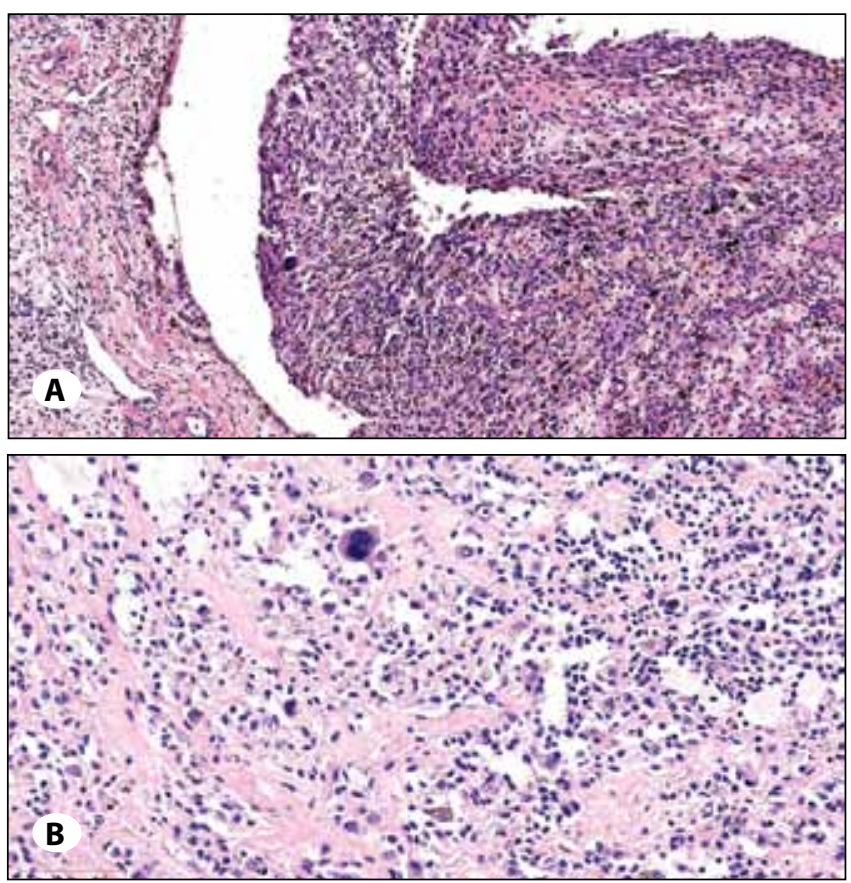

Figure 4: A) The tumors comprise an admixture of mononuclear histiocytoid cells, multinucleate giant cells, foam cells, siderophages, and inflammatory cells. Synovial-like spaces are present (hemotoxylin/eosin staining ( $\mathrm{HE}, \times 10$ magnification). B) A villous growth pattern was also detectable $(\mathrm{HE}, \times 20)$.

DTGCT or PVNS involving the spine is extremely rare, and no rigorous reviews were reported in the literature. We report herein 3 cases of spinal DTGCT at our institute and have performed a systematic review of the literature based on the current best evidence. Some scholars believe that primary spinal DTGCT originates from facet joint synovial tissue and mainly grows extra-articularly rather than in the interior of the joint space (11), mostly in the cervical and lumbar vertebrae and rarely in the thoracic spine $(13,15)$. Our study confirmed these beliefs, as women were more vulnerable to this type of tumor, $71.4 \%$ of spinal DTGCT/PVNS cases were reported to originate from facet joints, and $65.7 \%$ of these tumors expanded into the spinal canal. Overall, $77.1 \%$ of these tumors involved the cervical and lumbar spine.

DTGCT has no specific clinical and radiological manifestations; approximately $50 \%$ of patients have focal soft tissue mass shadows, which are occasionally accompanied by manifestations such as bone destruction, periosteal reactions, and calcification within the lesion $(21,28)$. CT can identify pathological changes of the facet joint, bone destruction, and eroded adjacent vertebral bodies. MRI often shows equal or higher signals than muscle on T1-weighted images, whereas the features on T2-weighted images vary and can be characterized by hypointense, isointense, or hyperintense signals. The lack of specific MRI features can lead to confusion when distinguishing between giant cell tumors of the bone and aneurysmal bone cysts (24).

Pathological manifestations provide the main diagnostic evidence. Histologically, DTGCT is characterized by the presence of monocytes and varying amounts of multinucleated giant cells, foam cells, chronic inflammatory cells, and hemosiderin (13). In the present study, all patients underwent preoperative CT-guided biopsies, followed by histological and immunohistochemical analyses. For all 3 cases, the DTGCT diagnoses were preoperatively confirmed. Immunohistochemically, the biopsy specimens from all 3 cases were positive for vimentin and CD68, suggesting that monocytes comprised the majority of reactive cells in these DTGCT. These findings were consistent with the pathological characteristics of TGCT. Therefore, preoperative CT-guided biopsy is an important method for preoperative diagnoses and treatment strategy decisionmaking.

GTR was the best treatment strategy, according to our systematic review. The recurrence rate of patients who underwent GTR was only $7.7 \%$, and tumor progression was observed in $66.7 \%$ of patients who underwent subtotal resection. Additionally, 2 cases of malignant transformation were observed in patients who underwent subtotal resection. In the present study, all 3 patients received extra-capsular total resections, and no tumor recurrence was observed during the long-term follow-up period. Recently, the intraoperative application of $300-\mathrm{mCi}$ radiotherapy-assisted surgery has been shown to significantly reduce the postoperative recurrence rate of DTGCT of the knee joint (5). Furthermore, some scholars attempted to treat TGCT in the articulations of the appendicular skeleton with imatinib-targeted therapy (2). However, no such treatments were reportedly applied to spinal DTGCT.

\section{CONCLUSION}

In summary, primary spinal DTGCT is rarely reported. Diagnosis mainly depends on histological and immunohistochemical analyses. CT-guided biopsy is an important diagnostic method. GTR is the best treatment strategy and can reduce the recurrence rate. 

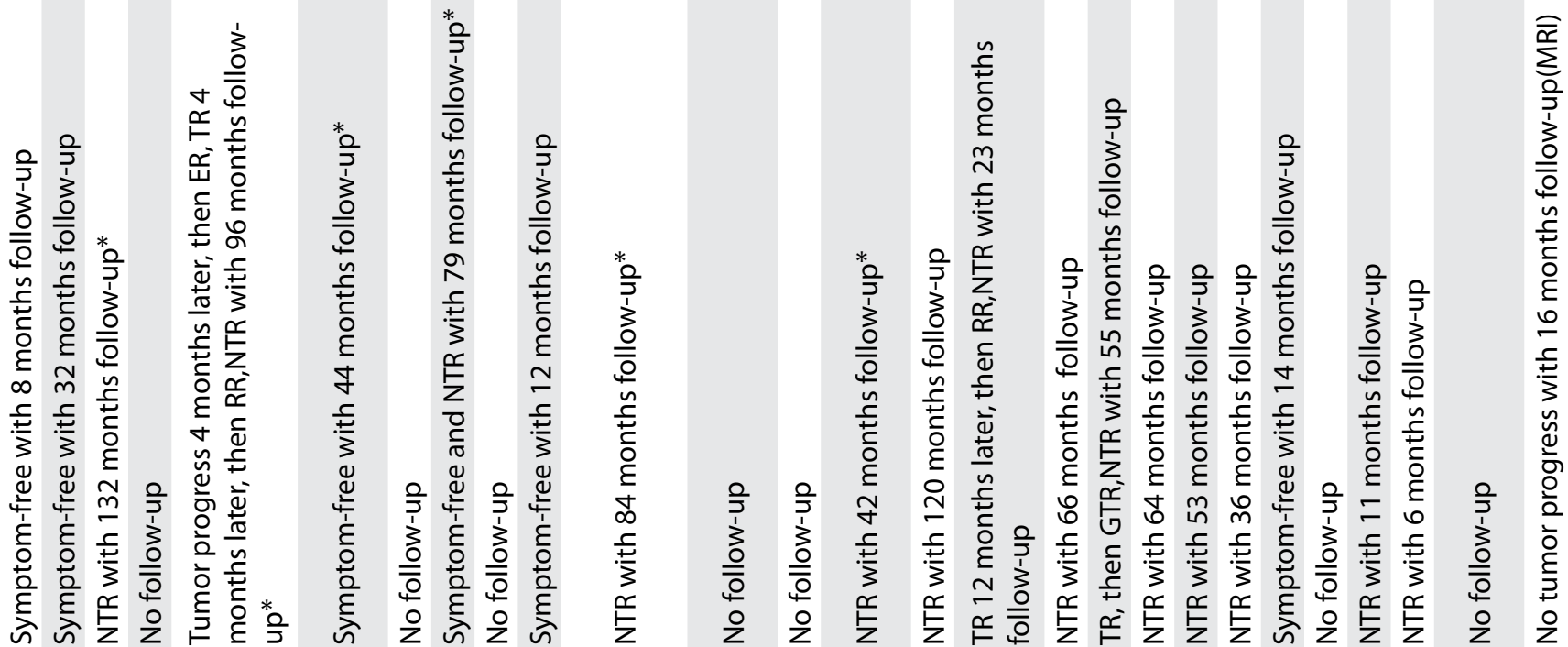

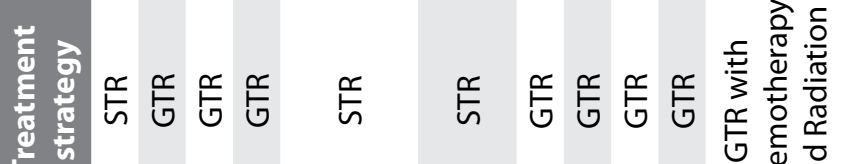



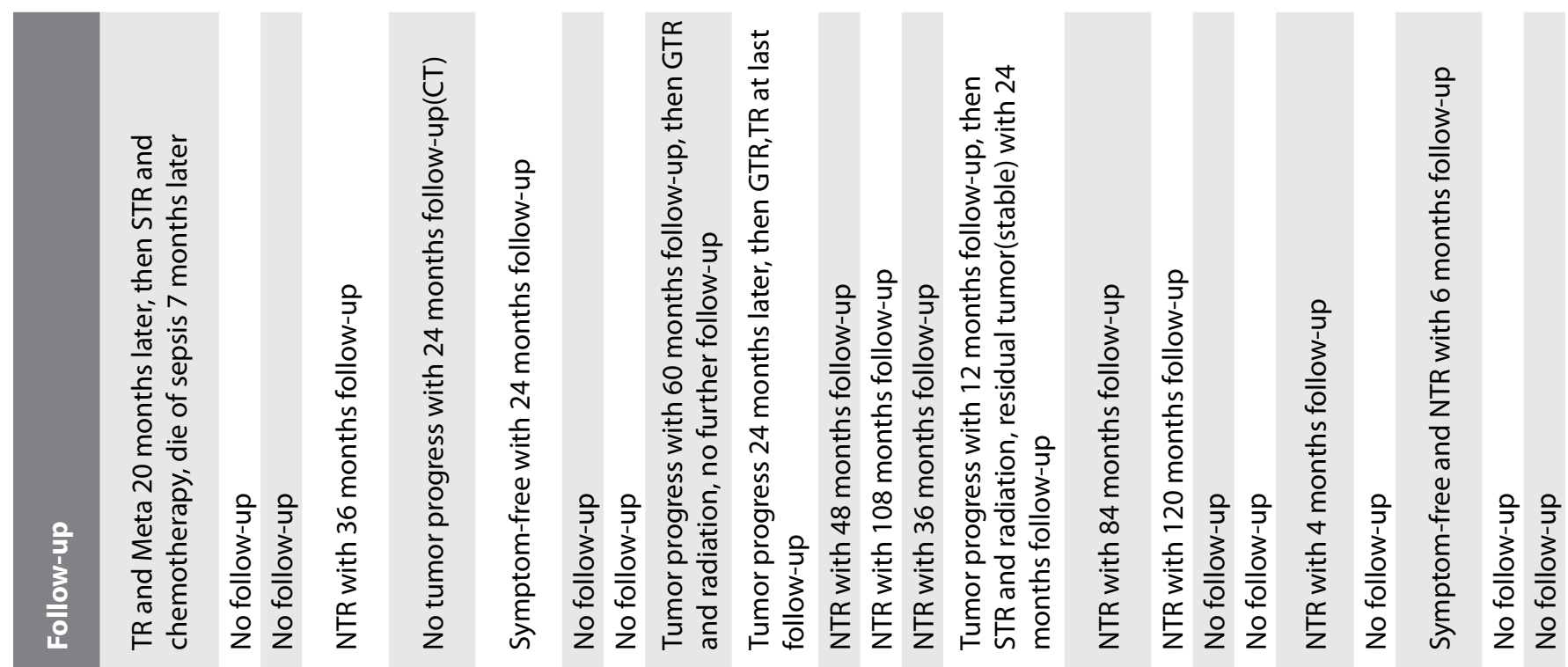

量

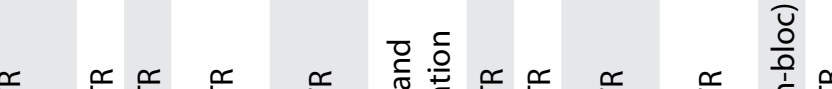

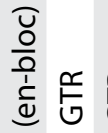
产

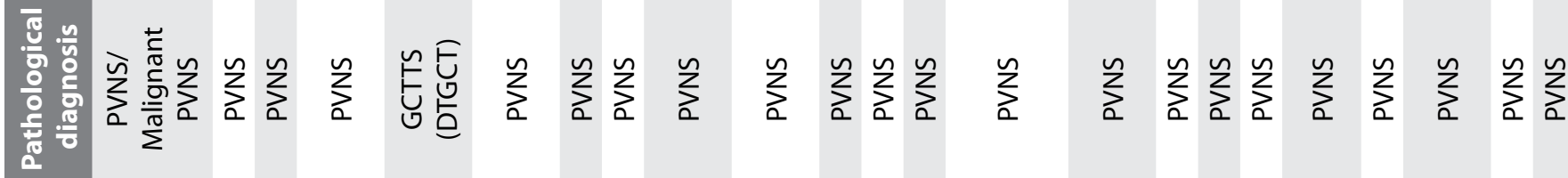

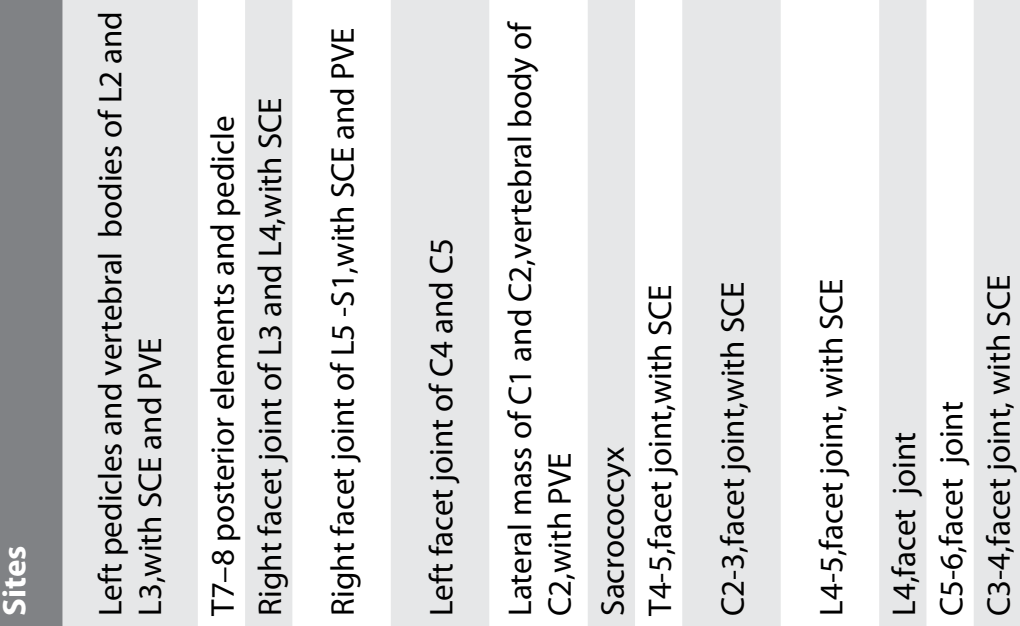

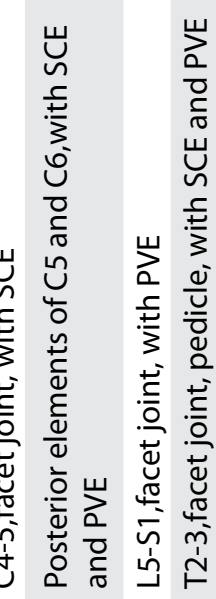

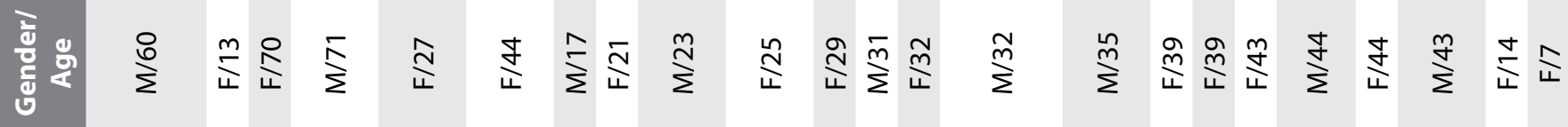

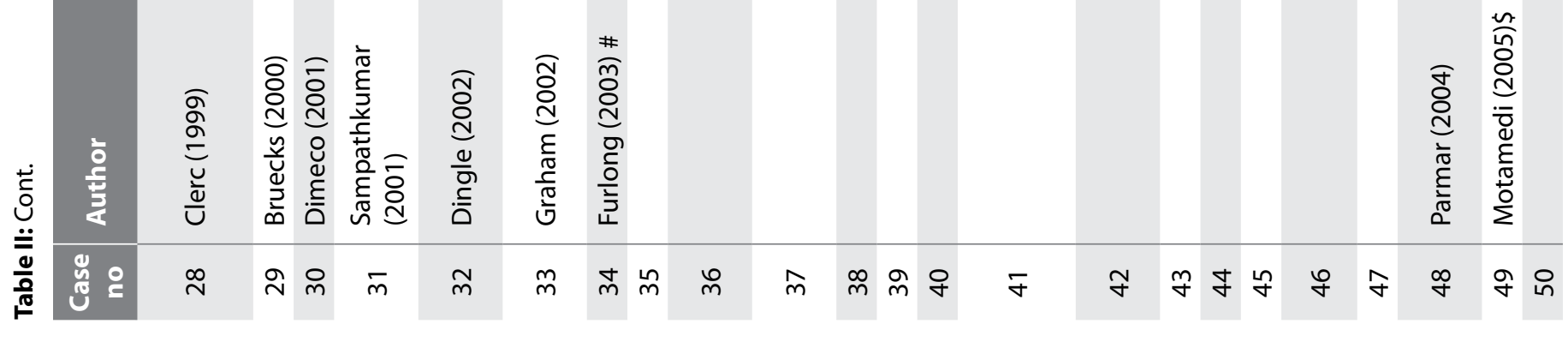



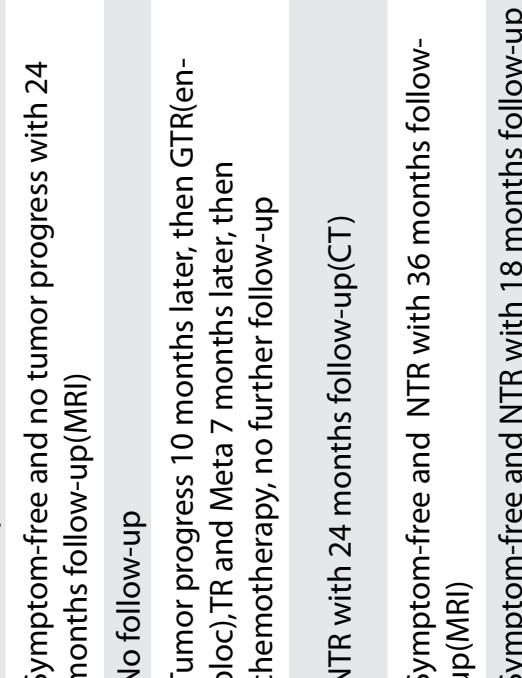

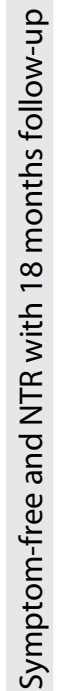
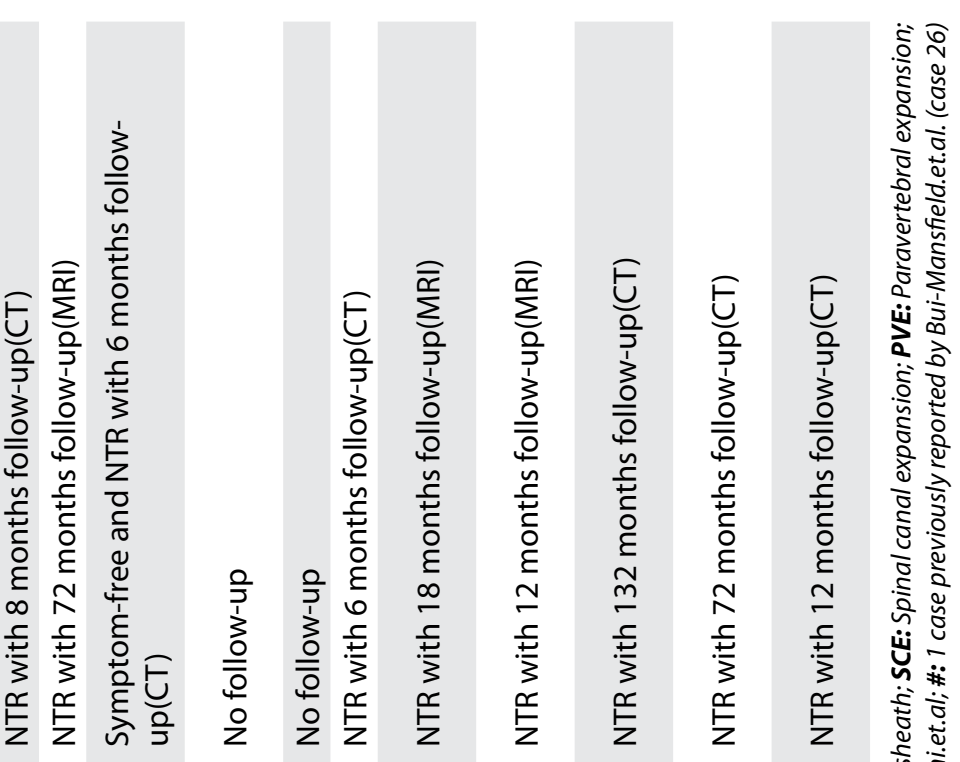

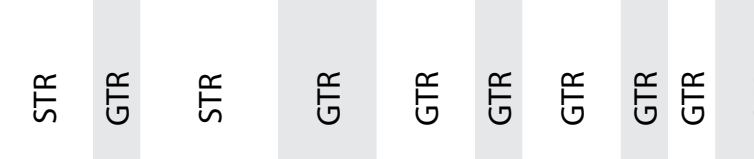

部品以

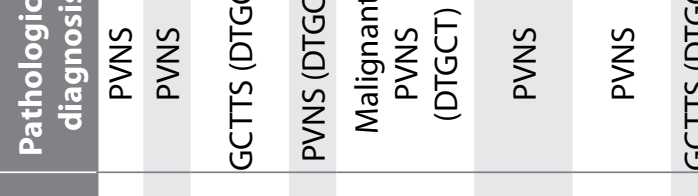

g.

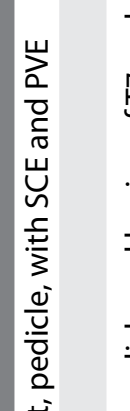

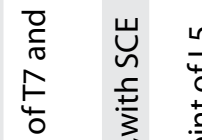

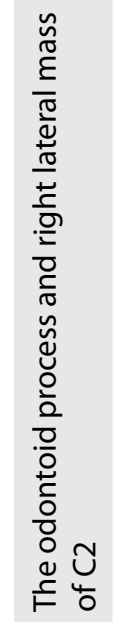

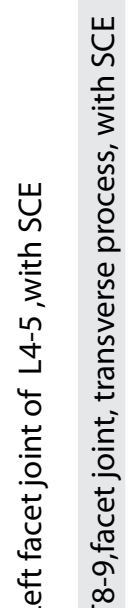

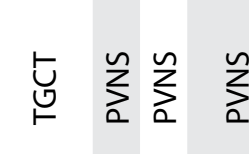

E E

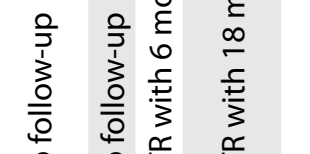




\section{REFERENCES}

1. Blankenbaker DG, Tuite MJ, Koplin SA, Salamat MS, Hafez $\mathrm{R}$ : Tenosynovial giant cell tumor of the posterior arch of $\mathrm{C} 1$. Skeletal Radiol 37(7): 667-671, 2008

2. Blay JY, El SH, Thiesse P, Garret J, Ray-Coquard I: Complete response to imatinib in relapsing pigmented villonodular synovitis/tenosynovial giant cell tumor (PVNS/TGCT). Ann Oncol 19(4): 821-822, 2008

3. Bruecks AK, Macaulay RJ, Tong KA, Goplen G: November 2000: 13 year old girl with back pain and leg weakness. Brain Pathol. 11(2): 263-264, 2001

4. Bui-Mansfield LT, Youngberg RA, Coughlin W, Chooljian D: MRI of giant cell tumor of the tendon sheath in the cervical spine. J Comput Assist Tomogr 20(1): 113-115, 1996

5. Campbell AJ, Wells IP: Pigmented villonodular synovitis of a lumbar vertebral facet joint. J Bone Joint Surg Am 64(1): 145-146, 1982

6. Clark LJ, McCormick PW, Domenico DR, Savory L: Pigmented villonodular synovitis of the spine. Case report. J Neurosurg 79(3): 456-459, 1993

7. Clerc D, Berge E, Benichou O, Paule B, Quillard J, Bisson M: An unusual case of pigmented villonodular synovitis of the spine: Benign aggressive and/or malignant. Rheumatology (Oxford). 38(5): 476-477, 1999

8. del CBL, Rosales OLM, Arriaga NM, Izaguirre A, Pineda C: Pigmented villonodular synovitis of thoracic facet joint presenting as rapidly progressive paraplegia.J Clin Rheumatol 15(8): 393-395, 2009

9. Dimeco F, Rizzo P, Li KW, Ciceri E, Casali C, Pollo B, Lasio G: Pigment villonodular synovitis of the spine. Case report and review of the literature. J Neurosurg Sci 45(4): 216-219; discussion 219, 2001

10. Dingle SR, Flynn JC, Flynn JC Jr, Stewart G: Giant-cell tumor of the tendon sheath involving the cervical spine. A case report. J Bone Joint Surg Am 84-A(9): 1664-1667, 2002

11. Doita $M$, Miyamoto $H$, Nishida $K$, Nabeshima $Y$, Yoshiya $S$, Kurosaka M: Giant-cell tumor of the tendon sheath involving the thoracic spine. J Spinal Disord Tech 18(5): 445-448, 2005

12. Finn MA, McCall TD, Schmidt MH: Pigmented villonodular synovitis associated with pathological fracture of the odontoid and atlantoaxial instability. Case report and review of the literature. J Neurosurg Spine 7(2): 248-253, 2007

13. Furlong MA, Motamedi K, Laskin WB, Vinh TN, Murphey M, Sweet DE, Fetsch JF: Synovial-type giant cell tumors of the vertebral column: A clinicopathologic study of 15 cases, with a review of the literature and discussion of the differential diagnosis. Hum Pathol 34(7): 670-679, 2003

14. Gezen F, Akay KM, Aksu AY, Beduk A, Seber N: Spinal pigmented villonodular synovitis: A case report. Spine (Phila Pa 1976) 21(5): 642-645, 1996

15. Giannini C, Scheithauer BW, Wenger DE, Unni KK: Pigmented villonodular synovitis of the spine: A clinical, radiological, and morphological study of 12 cases. J Neurosurg 84(4): 592-597, 1996
16. Graham EJ, Kuklo TR, Kyriakos M, Rubin DA, Riew KD: Invasive pigmented villonodular synovitis of the atlantoaxial joint: $A$ case report. J Bone Joint Surg Am 84-A(10): 1856-1860, 2002

17. Gupta R, Jambhekar N, Sanghvi D: Giant-cell tumour of the synovium in a facet joint in the thoracic spine of a child. J Bone Joint Surg Br 90(2): 236-239, 2008

18. Hansen MA, Harper C, Yiannikas C, McGee-Collett M: A rare presentation of pigmented villonodular synovitis. J Clin Neurosci 14(4): 386-388, 2007

19. Hermann J, Stadlmaier E, Ch A, Spuller E, Reittner P, Graninger W: Erosive intervertebral joint lesions. A case of pigmented villonodular synovitis. Z Rheumatol 66(2): 152, 154-156, 2007

20. Hsieh YC, Chen WY, Hsieh TY, Chan WP: Pigmented villonodular synovitis of the lumbar spine. J Clin Rheumatol 18(5): 274-275, 2012

21. Karasick D, Karasick S: Giant cell tumor of tendon sheath: Spectrum of radiologic findings. Skeletal Radiol 21(4): 219224,1992

22. Karnezis TA, McMillan RD, Ciric I: Pigmented villonodular synovitis in a vertebra. A case report. J Bone Joint Surg Am 72(6): 927-930, 1990

23. Khoury GM, Shimkin PM, Kleinman GM, Mastroianni PP, Nijensohn DE: Computed tomography and magnetic resonance imaging findings of pigmented villonodular synovitis of the spine. Spine (Phila Pa 1976) 16(10):1236-1237, 1991

24. Kitagawa $Y$, Ito $H$, Amano $Y$, Sawaizumi T, Takeuchi T: MR imaging for preoperative diagnosis and assessment of local tumor extent on localized giant cell tumor of tendon sheath. Skeletal Radiol 32(11): 633-638, 2003

25. Kleinman GM, Dagi TF, Poletti CE: Villonodular synovitis in the spinal canal: Case report. J Neurosurg 52(6): 846-848, 1980

26. Kuwabara $\mathrm{H}$, Uda $\mathrm{H}$, Nakashima $\mathrm{H}$ : Pigmented villonodular synovitis (giant cell tumor of the synovium) occurring in the vertebral column. Report of a case. Acta Pathol Jpn 42(1): 69-74, 1992

27. Mahmood A, Caccamo DV, Morgan JK: Tenosynovial giantcell tumor of the cervical spine. Case report. J Neurosurg 77(6): 952-955, 1992

28. Motamedi K, Murphey MD, Fetsch JF, Furlong MA, Vinh TN Laskin WB, Sweet DE: Villonodular synovitis (PVNS) of the spine. Skeletal Radiol 34(4):185-195, 2005

29. Musluman AM, Cavusoglu H, Yilmaz A, Dalkilic T, Tanik C, Aydin Y: Pigmented villonodular synovitis of a lumbar intervertebral facet joint. Spine J 9(8): e6-9, 2009

30. Myers BW, Masi AT: Pigmented villonodular synovitis and tenosynovitis: A clinical epidemiologic study of 166 cases and literature review. Medicine (Baltimore) 59(3):223-238, 1980

31. Oda Y, Takahira T, Yokoyama R, Tsuneyoshi M: Diffuse-type giant cell tumor/pigmented villonodular synovitis arising in the sacrum: Malignant form. Pathol Int 57(9): 627-631, 2007

32. Oe K, Sasai K, Yoshida Y, Ohnari H, lida H, Sakaida N, Uemura Y: Pigmented villonodular synovitis originating from the lumbar facet joint: A case report. Eur Spine J 16 Suppl 3: 301-305, 2007 
33. Okutan O, Solaroglu I, Ozen O, Saygili B, Beskonakli E: Tenosynovial giant cell tumor in the cervico-thoracic junction. Turk Neurosurg 22(6): 769-771, 2012

34. Olivier E, Defives T: Spinal locations of pigmented villonodular synovitis: Case report and review of the literature. Rev Chir Orthop Reparatrice Appar Mot 89(6): 549-557, 2003

35. Ottaviani S, Ayral X, Dougados M, Gossec L: Pigmented villonodular synovitis: A retrospective single-center study of 122 cases and review of the literature. Semin Arthritis Rheum 40(6): 539-546, 2011

36. Parmar HA, Sitoh YY, Tan KK, Teo J, Ibet SM, Hui F: MR imaging features of pigmented villonodular synovitis of the cervical spine. AJNR Am J Neuroradiol 25(1): 146-149, 2004

37. Pechlivanis I, Tannapfel A, Tuttenberg J, Harders A, Schmieder $\mathrm{K}$ : Pigmented villonodular synovitis involving the thoracic spine: A case report. Z Orthop Unfall 147(2): 220-224, 2009

38. Pulitzer DR, Reed RJ: Localized pigmented villonodular synovitis of the vertebral column. Arch Pathol Lab Med 108(3): 228-230, 1984

39. Ravi V, Wang WL, Lewis VO: Treatment of tenosynovial giant cell tumor and pigmented villonodular synovitis. Curr Opin Oncol 23(4): 361-366, 2011

40. Retrum ER, Schmidlin TM, TaylorWK, Pepe RG: CT myelography of extradural pigmented villonodular synovitis. AJNR Am J Neuroradiol 8(4): 727-729, 1987

41. Rovner J, Yaghoobian A, Gott M, Tindel N: Pigmented villonodular synovitis of the zygoapophyseal joint: A case report. Spine (Phila Pa 1976) 33(18): E656-658, 2008
42. Sampathkumar K, Rajasekhar C, Robson MJ: Pigmented villonodular synovitis of lumbar facet joint: A rare cause of nerve root entrapment. Spine (Phila Pa 1976) 26(10): E213-215, 2001

43. Savitz MH, Katz SS, Goldstein H, Worcester D: Hypertrophic synovitis of the lumbar facet joint in two cases of herniated intervertebral disc. Mt Sinai J Med 49(5): 434-437, 1982

44. Siribumrungwong K, Tangtrakulwanich B, Nitiruangjaras A: Unusual presentation of giant cell tumor originating from a facet joint of the thoracic spine in a child: A case report and review of the literature. J Med Case Rep 7(1): 178, 2013

45. Somerhausen NS, Fletcher CD: Diffuse-type giant cell tumor: Clinicopathologic and immunohistochemical analysis of 50 cases with extraarticular disease. Am J Surg Pathol 24(4): 479-492, 2000

46. Teixeira WG, Lara NA Jr, Narazaki DK, de Oliveira C, Cavalcanti C, Marins LV, Cristante AF, Teixeira MJ, de Barros Filho TE: Giant-cell tumor of the tendon sheath in the upper cervical spine. J Clin Oncol 30(26): e250-253, 2012

47. Titelbaum DS, Rhodes CH, Brooks JS, Goldberg HI: Pigmented villonodular synovitis of a lumbar facet joint. AJNR Am J Neuroradiol 13(1): 164-166, 1992

48. Weidner N, Challa VR, Bonsib SM, Davis CH Jr, Carrol TJ Jr: Giant cell tumors of synovium (Pigmented villonodular synovitis) involving the vertebral column. Cancer 57(10): 2030-2036, 1986

49. Yener U, Konya D, Bozkurt S, Ozgen S: Pigmented villonodular synovitis of the spine: Report of a lumbar case. Turk Neurosurg 20(2): 251-256, 2010 